\title{
E-MARKET BUAH LONTAR DESA HENDROSARI
}

\author{
Arini Sulistyowati ${ }^{1}$, Bagas Setya Putra ${ }^{2}$ \\ Universitas Wijaya Putra \\ $\underline{\text { arinisulistyowati@uwp.ac.id }}^{1}$ dan $\underline{\text { akunkerja.45@gmail.com }}^{2}$
}

\begin{abstract}
ABSTRAK
Desa Hendrosari berada di Kecamatan Menganti, Kabupaten Gresik, Jawa Timur. Desa Hendrosari memiliki luas 192 hektar sedangkan 75 hektar merupakan luasan area yang ditumbuhi pohon Siwalan (Lontar) yang menghasilkan Legen dan Buah Siwalan. Dari ratusan budidaya Pohon lontar di Desa Hendrosari sebagai kampung entrepreneur, penggerak utama kegiatan ekonomi menjadi Desa Wisata Alam dan Kuliner Lontar Sewu.

Perkembangan sekarang ini semakin maju dan modern, teknologi informasi dan komunikasi berkaitan perangkat digital dan internet. Desa Hendrosari sebagai kampung Entrepreneur membutuhkan promosi secara online melalui media internet dan kecanggihan teknologi digital dengan mudah dipantau dan prosesnya mudah untuk mengenalkan produk pohon lontar dan potensi desa Hendrosari, meningkatkan luas jangkauan pesan, membangun hubungan, imbal balik atau feedback,. Tetapi masyarakat hendrosari belum begitu merespon elektronik pemasaran yang dibuat perangkat desa, belum mengetahui bagaimana membuat dan mengelola elektronik pemasaran sehingga masyarakat membutuhkan pelatihan elektronik pemasaran.
\end{abstract}

Kata Kunci: Desa Hendrosari, elektronik pemasaran, kampung entrepreneur

\section{BAB 1 PENDAHULUAN}

\section{Analisis Situasi}

Perkembangan Ilmu pengetahuan dan teknologi yang semakin pesat memiliki dampak pada perilaku masyarakat Indonesia diharapkan dapat menjadi agent of change dalam memasarkan produk usahanya, semakin mengarah ke gaya hidup teknologi internet atau digital, memanfaatkan internet sebagai bagian dari strategi pemasaran dimana pemasaran penjualan produk mulai beralih dari belanja offline menuju belanja melalui internet (online) maupun branding produk. Elektronik pemasaran dapat menjangkau seluruh masyarakat dimanapun keberadaannya tanpa adanya batasan geografis ataupun waktu. Pemasaran secara emarketing ini mampu dapat menjadi cara yang sangat efektif untuk mengidentifikasi target pasar atau menemukan keinginan dan kebutuhan segmen pemasaran. Warga juga mampu menjangkau pasar global, menyajikan promosi dengan lebih menarik, mempermudah sistem pembelian dibanding dengan sistem offline.

Letak desa Hendrosari di Kecamatan Menganti, Gresik. Desa itu berbatasan dengan Benowo di sebelah timur dan Boboh di bagian barat. Pembagian lahan di desa Hendrosari sebagian besar adalah lahan pertanian pohon siwalan dan tanaman pangan padi di musim penghujan. Tanaman Jagung dan polowijo di musim kemarau serta memiliki produksi ayam panggang lokal khas desa tersebut. 
Tumbuh ratusan pohon lontar hanya di desa itu. Sedangkan, tumbuhan siwalan itu tidak bisa tumbuh di desa sekitar desa Hendrosari. Tumbuhan lontar memang identik dengan Tuban, Lamongan, dan daerah pantura sekitarnya. Desa Hendrosari lumayan jauh dari pantai utara Jawa, tetapi siwalan atau lontar bisa tumbuh dan berkembang.

\section{Gambar Lokasi Desa Hendrosari}
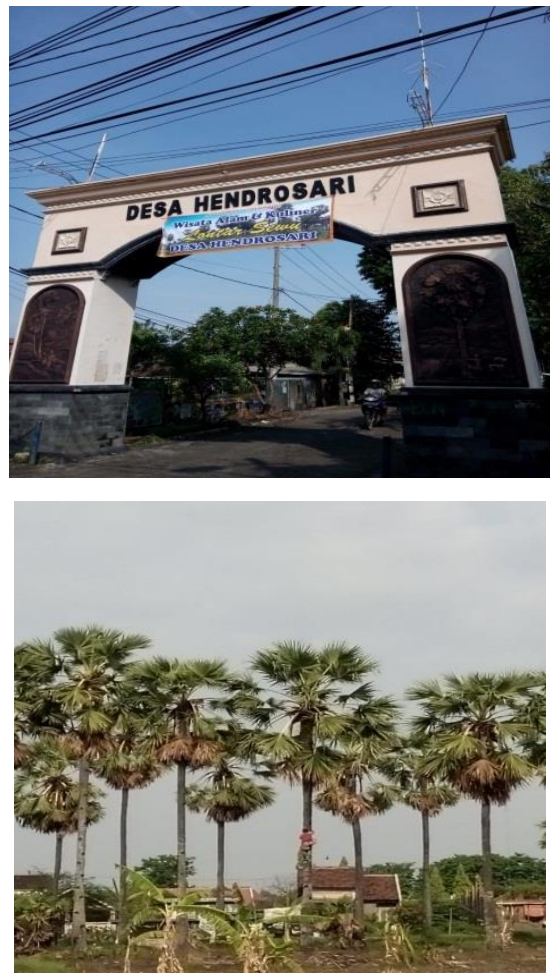

Permasalahan pelaku UMKM Desa Hendrosari, Kecamatan Menganti, Kabupaten Gresik, yaitu: omset penjualan produk di Desa Hendrosari tidak memiliki grafik meningkat, hanya bersifat verbal dari mulut ke mulut dengan jangkauan penjualan hanya di warga lokal saja, kurang memiliki inovasi dan edukasi pemasaran produk dalam segi teknologi internet dan media sosial dikarenakan masyarakat Hendrosari masih sedikit yang belum memahami bagaimana cara melakukan elektronik marketing dengan memanfaatkan media sosial serta kurangnya minat warga desa dalam mempelajari pemasaran berbasis teknologi ini karena dianggap masih tabu, dan warga yakin mampu memasarkan produk hanya secara verbal.

Masyarakat diharuskan melek teknologi internet, oleh karena itu diperlukannya sosialisasi, pelatihan dan edukasi warga tentang pemasaran berbasis teknologi. Kegiatan pengabdian masyarakat mengenai pemanfaatan elektronik pemasaran ini diharapkan dapat memberikan pengetahuan dan pemahaman serta dapat menginspirasi pelaku masyarakat Hendrosari dalam memanfaatkan teknologi internet dan jejaring sosial sebagai alat untuk menjalankan peluang usaha bisnis dari buah lontar.

\section{Permasalahan}

Berdasarkan kondisi obyektif sebagaimana terurai dalam analisis situasi di atas, maka dapat diidentifikasi terdapat permasalahan sebagai berikut:

1. Bagaimana pengetahuan dan pemahaman masyarakat Hendrosari mengenai elektronik marketing?

2. Bagaimana pengetahuan dan pemahaman masyarakat Hendrosari mengenai mempraktikkan elektronik marketing dengan memanfaatkan media sosial?

Tujuan Kegiatan

Tujuan yang diperoleh dari kegiatan ini adalah:

a. Peserta

1. Masyarakat Hendrosari mengehui dan memahami elektronik marketing bagi usaha bisnisnya;

2. Masyarakat Hendrosari dapat mempraktikkan elektronik marketing dengan memanfaatkan media sosial secara langsung;

3. Masyarakat Hendrosari dapat terinspirasi dan termotivasi untuk menggunakan elektronik marketing sebagai sarana komunikasi dan promosinya.

4. Masyarakat dapat mengetahui semua jenis produk yang dijual oleh Masyarakat Desa Hendrosari.

b. Tim Pengabdian Masyarakat

1. Tim pelaksana menyebarkan brosur dan undangan kepada warga hendrosari dan warga sekitar untuk mengikuti seminar dan pelatihan tentang pemasaran berbasis teknologi

2. Tim pelaksana menyampaikan manfaat dan pentingnya promosi pemasaran dari media konvensional menuju elektronik marketing pada peserta pelatihan. 
3. Tim pelaksana menunjukkan beberapa contoh pemasaran produk melalui online dari berbagai UMKM

4. Tim pelaksana memberikan kontribusi pendampingan, penyuluhan, pelatihan edukasi dan berbagi pengalaman kepada masyarakat dan pelaku UMKM Desa Hendrosari mengenai promosi pemasaran produk melalui elektronik marketing;

5. Tim pelaksana mendemonstrasikan proses promosi pemasaran produk melalui elektronik marketing.

6. Tim pelaksana melakukan pembinaan kepada pemilik produk dan UMKM yang ada di Desa Hendrosari.

\section{BAB II TARGET DAN LUARAN}

\section{Target}

Pelaksanaan Pengabdian ini untuk mendukung pemasaran produk, adapun target yang hendak dicapai adalah :

a. Menjadikan warga desa mengerti tentang pemasaran produk berbasis teknologi.

b. Mampu mengembangkan potensi desa terutama pada pemasaran produk berbasis teknologi.

c. Menciptakan masyarakat mandiri dengan Pelatihan E-Marketing Di Desa Hendrosari

d. Masyarakat mampu memanfaatkan dengan optimal website Desa hendrosari dan media sosial untuk mengembangkan pemasaran produk.

\section{Luaran}

Luaran yang hendak diupayakan dan dicapai melalui kegiatan pengabdian ini adalah: kemampuan masyarakat Hendrosari memasarkan produknya melalui internet (online).

\section{BAB III. METODE KEGIATAN}

Kegiatan pengabdian pada masyarakat ini ditujukan untuk memberikan pengetahuan dan keterampilan pembuatan pemasaran via online. Metode yang digunakan kegiatan ini yaitu presentasi, demonstrasi, dan praktik secara individu maupun kelompok.
1. Metode presentasi dan tanya Jawab

Metode ini digunakan untuk menyampaikan teori, konsep-konsep yang sangat prinsip dan yang berkaitan dengan manfaat, fungsi, bagaimana cara pembuatan pemasaran via online, mulai dari awal sampai akhir untuk dimengerti serta dikuasai oleh peserta pelatihan. Metode ini juga memberikan kesempatan kepada peserta pelatihan untuk bertanya sehingga komunikasi dapat dilakukan dua arah..

2. Metode Demonstrasi

Metode ini digunakan untuk menunjukkan suatu proses kerja sehingga dapat memperjelas pemahaman peserta pelatihan. Dengan demikian peserta dapat mengamati secara sempurna teknik-teknik yang diberikan. Metode untuk mempertunjukkan cara pembuatan pemasaran via online dengan diharapkan dengan adanya metode ini para peserta dapat mempraktikkan langsung membuat pemasaran produknya via online.

3. Metode Praktik

Setiap tahapan teknik didemonstrasikan oleh instruktur kemudian langsung diikuti oleh latihan para peserta pelatihan. Metode ini dilakukan untuk melatih masyarakat dan pelaku UMKM Desa Hendrosari melakukan pemasaran produknya via online. Metode ini dilakukan agar masyarakat dan para pelaku UMKM Desa Hendrosari memiliki pengalaman langsung mengenai pemasaran produknya via online.

\section{Gambar Tampilan Produk Website}

\section{hendrosariku.com}

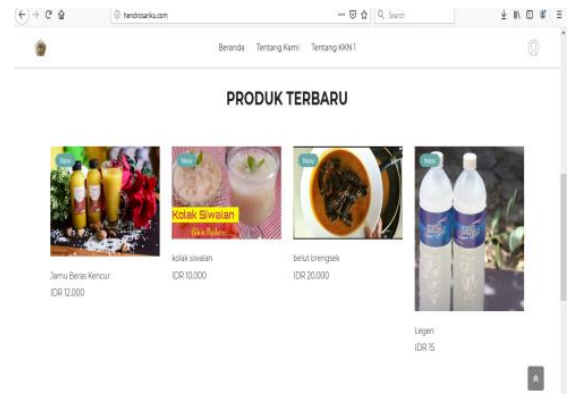

PROSIDING PKM-CSR 2019 


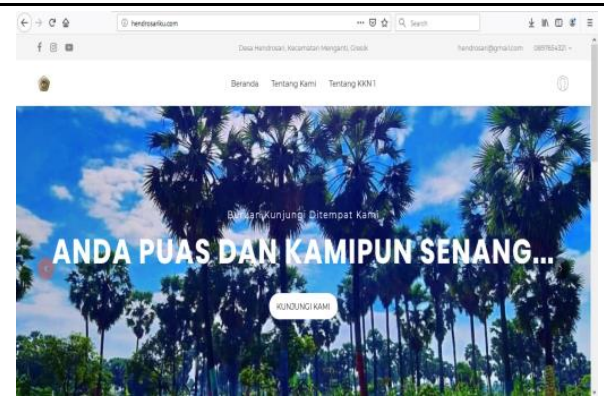

\section{Hasil dan Pembahasan}

Pemberian pelatihan pemasaran melalui online diberikan dengan bahan pemasaran produk secara umum sehingga masyarakat dan para pelaku UMKM Hendrosari memahami penjelasan dan contoh beberapa pemasaran melalui online. Saat pelatihan berlangsunh tidak hanya cerita tentang teori tetapi lebih terhadap pembahasan masalah pemasaran yang mereka hadapi selama ini seperti sulitnya memperluas pasar, ketidaktahuan untuk melakukan alat promosi dan pentingnya pengembangan produk.

Teknologi informasi dalam pemasaran produk melalui online Desa Hendrosari sangat berpotensi untuk:

1. sarana kontak personal dengan pembeli, sarana promosi produk, mendata kebutuhan pembeli, menyampaikan respon ke masyarakat, dan sebagai dasar pengambilan keputusan bisnis

2. Mendorong promosi pemasaran sehingga masyarakat lebih mengenal pemasaran produk melalui online, mengembangkan produk dan meningkatkan omzet penjualan

3. Mengembangkan jaringan pasar yang lebih luas lagi dan melakukan komunikasi dengan konsumen, penyalur maupun pemasok

4. Masyarakat mampu praktek secara langsung bagaimana cara pengambilan foto guna mendukung dan menjadi daya tarik pembeli untuk tertarik melihat dan membeli produk mereka

5. Pemberian website hendrosariku.com kepada perangkat desa yang akan disalurkan ke masyarakat untuk mengenalkan produk penjualan desa Hendrosari ke masyarakat luar.

6. Masyarakat ikut berpartisipasi dalam kontes foto di lontar sewu guna mengenalkan wisata lontar sewu hendrosari ke masyarakat luar

\section{Simpulan}

Serangkaian kegiatan pelatihan yang dilaksanakan dalam kegiatan Pengabdian Masyarakat ini menunjukkan bahwa masyarakat dan para pelaku UMKM Desa Hendrosari perlu memiliki peningkatan pemahaman materi dan potensi untuk mengembangkan usaha.

\section{Ucapan Terima kasih}

Penulis menghaturkan terima kasih kepada:

1. Bapak Budi Endarto, SH., M.Hum selaku Rektor Universitas Wijaya Putra

2. Dr.Nugroho Mardi W, M.Si. selaku Ketua Kepala Lembaga Penelitian dan Pengabdian Masyarakat

3. Dr. Sri Juni Woro Astuti., M.Com selaku Dekan Fakultas Ilmu Sosial dan Ilmu Politik Universitas Wijaya Putra.

4. Supriyanto, S.Sos., M.Si selaku Ketua Program Studi Ilmu Administrasi Negara Fakultas Ilmu Sosial dan Ilmu Politik Universitas Wijaya Putra.

5. Eny Nur Muchlis selaku pejabat setempat Desa Hendrosari.

\section{Referensi}

Agustina, Tri Siwi. (2015). Kewirausahaan: Teori dan Penerapan pada Wirausaha dan UKM di di Indonesia. Jakarta: Mitra Wacana Media.

Kannan, P. K., \& Hongshuang, L. (2016). Digital Marketing: A Framework, Review and Research Agenda. International Journal of Research in Marketing .

Stelzner, M. (2012, April). How Marketers are Using Social Media to Grow Their Business.

Wardhana, A. (2015). Strategi Digital Marketing dan Implikasinya pada Keunggulan Bersaing UKM di Indonesia.

Mengunjungi Desa Hendrosari, Desa Produsen Legen yang Legend. https://dnk.id/liputan/ismailsurendra/mengunjungi-desa-hendrosaridesa-produsen-legen-yang-legend-yX8Rd diakses pada hari Selasa, 10 September 2019 Pukul 10.35 Wib 